\title{
Reading Fiction with Levinas: Ian McEwan's novel Atonement
}

What does it mean to read fiction through the lens of Levinas's ethics? How does literary criticism benefit from Levinas's philosophy? In this article I explore the relevance of Levinas's thought to contemporary ethical criticism as exemplified by a reading of Ian McEwan's novel Atonement (2001). Ethical criticism is not a new field of inquiry. Rather, "for roughly 2500 years, ethical references constituted the starting point (and often the ending point) for most literary commentary" (Marshall 2010, 273). However, with the rise of literary theory during the twentieth century, traditional forms of ethical criticism were challenged and repudiated. ${ }^{1}$ Since the late 1980s, a general turn to philosophical ideas in literary studies has led to the reemergence of ethical criticism, a shift in which Levinas's ideas have played a major role. Levinas's notions of subjectivity, otherness, responsibility, and signification have deeply affected the discourse of literary criticism and inspired critical reexamination of the ethical possibilities of literary texts.

On one hand, Levinas's thought constitutes a departure from the ethics of empathetic reading which was central to nineteenth-century traditions of ethical criticism, ${ }^{2}$ and was later advanced by the neo-humanist strand in literary studies. ${ }^{3}$ According to this tradition, empathetic reading is an aesthetic experience with ethical affect: by entering into the feelings and thoughts of various characters, the readers open their eyes to new perspectives and expand their understanding of both other people and themselves. ${ }^{4}$ By contrast, for Levinas, rather than being ethically significant, empathetic imagination presents the common tyranny of the "same": it involves a presumptive knowledge of the other, based on a denial of his/her special uniqueness that enables comprehension and identification. ${ }^{5}$

1 See Gregory Marshall (2010, 273-277); Dorothy Hale (2007, 187-188);

2 On Victorian ethical criticism see Rohan Maitzen (2005, 151-185) and Rae Greiner (2012).

3 For more on this approach see Martha Nussbaum (2001, 59-77). See also Namwali Serpell (2014, 293-302).

4 See, for example, Gregory Currie (1995, 257), Noël Carroll (2002, 3-26), and Mary-Catherine Harrison (2008). See also the collection edited by Meghan Marie Hammond and Sue J. Kim, Rethinking Empathy through Literature (2014).

5 For a critical view of empathy in Levinas's thought, see Tammy Amiel Houser and Adia Mendelson- Maoz (2014, 199-218). 
On the other hand, Levinas does not see the other as the marginalized construction of a dominant system, caught up within an oppressive order from which it should be liberated. As Shameem Black notes, this view of otherness underlies critical theories in literary studies that focus on "hegemonic domination and representational violence” (Black 2010, 3). What Levinas's thought offers to these approaches is an acknowledgment of alterity that is not dependent or reduced to the dynamics of logo-centrism, phallocentrism, or Western imperialism: "the other absolutely other" (Levinas 2002 [1969], 41). In Levinas's philosophy Autrui "does not negate the same" and does not function as a constituent of self-consciousness (Levinas 2002 [1969], 203). Rather, human otherness signifies a special uniqueness that disturbs "the being at home with oneself," while demanding answerability and producing responsibility for the other (Levinas 2002 [1969], 39). Thus, instead of focusing on the submission and exploitation of the other and on relations of oppression, Levinas calls attention to "the access to the alterity of the Other" and the unconditional responsibility this access to the other creates (Levinas 2002 [1969], 121).

This approach to alterity and responsibility has inspired intriguing investigations in the literary field, for it raises important questions: can literature enable an encounter with the singularity of the other? In what ways and forms? Or, as Jill Robbins formulates it in her illuminating book on Levinas and literature: "Does the work of art give access to the ethical, as Levinas understands it?" (Robbins 1999, 75). Notably, although Robbins makes it clear that Levinas's response should be understood as "a resounding no" (Robbins 1999, 75; italics in original) since literary representation cannot deal with the non-representational essence of alterity, she and other literary scholars believe that it deserves further scrutiny. ${ }^{6}$ Indeed, this investigation has become the major concern of poststructuralist ethical criticism, as scholars try to overcome the limits that Levinas placed on the relations between literature and ethics, without abandoning his view of the ethical.

It is worth noting that in his treatment of language, Levinas himself suggested that literature could be further explored as giving access to the ethical. Derrida's early deconstructive reading of Totality and Infinity drew attention to the relationships between language and ethics in Levinas's thought and opened the door for literary scholars to engage in the debate. In his essay "Violence

6 Robert Eaglestone began to explore this question in his Ethical Criticism (1997), which was published before Robbins's book. For later studies see the collection In Proximity: Emmanuel Levinas and the Eighteenth Century, edited by Melvyn New with Robert Bernasconi and Richard A. Cohen (2001), and Levinas and Nineteenth-Century Literature: Ethics and Otherness from Romanticism to Realism, edited by Donald R. Wehrs and David P. Haney (2009). 
and Metaphysics,” Derrida appraises Levinas's important challenge to Western metaphysics, claiming that Totality and Infinity aims at acknowledging the "unthinkable truth" of the face-to-face relation, "the truth to which the traditional logos is forever inhospitable” (Derrida 1978, 90). However, Derrida concurrently criticizes Levinas's style of writing: by its ontological terminology and linguistic tendency to clearly represent the unthinkable ethical relation, it joins the metaphysical violence that it opposes. Levinas's later Otherwise than Being or beyond Essence is often understood as an implied response to Derrida's analysis of the relations between language and the violence of ontological thought. ${ }^{7}$ In this book, Levinas attempts to escape the phenomenal terminology of his early writings by translating the face-to-face relation into linguistic terms that are actually performed in the text. He insists that the ethical command be enacted in discourse, in the linguistic relation between the self and the other.

This understanding of the ethical is based on Levinas's distinction between the content of speech, meanings and themes, what Levinas terms the Said ["dit"], and the performative dimension of the linguistic address to another, termed the Saying [“dire”]. The Saying, which is interwoven with the Said, amounts to a special register of language; it is a modality of responsiveness and contact created through speech without any conscious intention on the part of the speaking subject (see Levinas 1991a [1974], 48-49). Hence, a discursive event brings the face-to-face relation into being, creating "the contact of saying” with the other (Levinas 1991a [1974], 85), to whom the speaking subject answers with the ethical declaration "here I am." According to Levinas, this biblical declaration expressed by Abraham to acknowledge his total obedience to God's command, ${ }^{8}$ is embodied in the linguistic relation that admits the infinite obligation of the speaking subject to her addressee. ${ }^{9}$

This Levinasian conception of language is crucial for literary criticism, which deals with linguistic constructions. If the Said and the Saying are interwoven in discourse, then literary works cannot be seen as devoid of the ethical, as Levinas often suggests (Robbins 1999, 77-78). Rather, as Robert Eaglestone claims, "the Saying can be understood as occurring in literary discourse as

7 This interpretation of Otherwise than Being was suggested by Robert Bernasconi and Simon Critchley in their collection Re-reading Levinas (1991, xiii). See also Critchley (1999, 12). See also Eaglestone's discussion of the literary style of Otherwise than Being (Eaglestone 1997, 136-146). Levinas's explicit response to Derrida is presented in his essay "Wholly Otherwise" (1991b [1973], 3-8).

8 See for example Genesis 22:1-14.

9 On the biblical 1 expression "me voici" (Here I am) and its ethical importance see Levinas (1991a [1974], 64-67, 142, 228-232). 
much as in philosophical discourse" (Eaglestone 1997, 163). Literature, therefore, can be explored as a linguistic construction that extends beyond the totalizing structures of representation and is able to signify the ethical obligation to the other. For Joseph G. Kronick this remains the main challenge for literary ethics: "Can literature perform the equivalent of extracting the otherwise than being from the Said in which it comes to light? Can it undo the thematization in which what cannot be thematized is represented?” (Kronick 2016, 266). Kronick argues that "for literary criticism, this means that any reading that remains thematic operates on the level of the Said and cannot account for the original relationship to the Other or the ethical" (Kronick 2016, 270). However, it should be recalled that the Saying always operates through the Said and is intermingled with the thematic level of discourse. Therefore, accounting for "the original relationship to the Other" requires working through the thematic level of the literary work, exploring the disruption of the Said, or as Simon Critchley writes, "the ways in which the Said can be unsaid" (Critchley 1999, 8).

In the last few decades, Levinas's conception of the ethical relation as embodied in the linguistic Saying has led to a resurgence of poststructuralist ethical criticism. Drawing on Levinas, literary scholars have explored the ways in which "the face accomplishes its breakthrough or divestiture of form" in various literary contexts (Robbins 1999, 24-25). Derek Attridge, for example, looks into "how otherness is engaged, staged, distanced, embraced, how it is manifested in the rupturing of narrative discourse” in J. M. Coetzee's fiction (Attridge 2004, 670); and Rachel Hollander analyzes "the profound ambivalence about the ability of the realist form to do full justice to an ethics of otherness" as developed in George Eliot's Daniel Deronda (Hollander 2009, 284). Even critics who are not committed to Levinas's thought are often deeply affected by "the Levinasian tradition of conceptualizing ethical obligation” (Black 2010, 44). Black in particular draws on Levinas in her search for a literary "breakthrough that allows for the encounter with significant otherness once considered impossible" (Black 2010, 44).

Reading fiction through Levinas thus requires a willingness to undergo the disturbing experience of being in touch with the impossible and the incomprehensible. It is difficult because, as David Palambu-Liu writes, "storytelling attempts to 'bridge' the distance between self and other” (Palambu-Liu 2012, 29). Reading a story is indeed a process of bridging: an attempt at decoding and connecting, understanding, and circumscribing different signs into coherent structures of meaning. It is also a process of relating with unknown characters and narrators in ways that make the stranger become familiar and comprehensible. Radical otherness, however, thwarts this process of bridging and understanding, by affecting what Palambu-Liu describes as “the crisis of representation” (Palambu Liu 2012, 30) 
and what Judith Butler characterizes as "that very disjunction that makes representation impossible” (Butler 2004, 144). Thus, the encounter with the singularity of the other rests on an ongoing negotiation in the reading process between sameness and difference, between the desire to comprehend and the willingness to endorse the incomprehensible. It demands an awareness of the reader's desire for empathetic identification - that connection which rests on similarity - and a contrary willingness to face what "destroys and overflows" such a connection (Levinas 2002 [1969], 51). In what follows, I examine this approach through a Levinasian reading of Ian McEwan's Atonement, a novel that puts forward a metafictional reflection on the relations between literature and the ethical.

\section{Giving Access to the Ethical: Ian McEwan's Atonement}

Written at the beginning of the new millennium, and looking back at the history of Europe in the twentieth century, Atonement is a good test for ethical criticism because it engages with questions of responsibility and ethical repair. Is there a way to atone for crimes against a fellow creature? Is it possible to restore justice after it has been violated? And can fiction contribute to these attempts at ethical rehabilitation? The protagonist of the novel, Briony Tallis, is guilty of giving false testimony that sends her elder sister's boyfriend, Robbie Turner, to prison for molesting her cousin Lola. Although the novel centers on a personal relationship, its scope is more than a private affair, since it links the local story to a larger social and cultural context and to the pervasive sense of anxiety around World War II. I argue that beyond the thematic preoccupation with ethical questions, in its structure and narration the novel also explores the possibility of giving access to the "pre-original saying" of the human condition (Levinas 1991 [1974], 6).

The thematic center of the novel is a transgression. It unfolds in the first section of the novel, told by an omniscient third-person narrator who looks closely at the main characters - Briony, her sister Cecilia, and Robbie - while shifting between their separate perspectives. The transgression occurs on a hot summer day in 1935 when a family gathering at the Tallises' aristocratic estate turns into a nightmare. The elitist serenity with its "impression of timeless, unchanging calm” (McEwan 2002, 19) - based on the Tallises' disregard for both personal and social tensions and injustices ${ }^{10}$ - collapses abruptly when the

10 On class experience in Atonement see Ian Fraser (2013). 
twin cousins disappear, Lola is attacked, and thirteen-year-old Briony accuses Robbie - the son of the cleaning woman, and Cecilia's new lover - of committing the sexual attack.

The second section of the novel takes Robbie's perspective and tells of his experience as a soldier in the awful retreat to Dunkirk in 1940. Robbie's story reveals how his life has been ruined by Briony's accusation, which led to his incarceration. He sees the war as just another facet of his own decline: "A dead civilization. First his own life ruined, then everybody else's” (McEwan 2002, 217). Tyrannical forces of destruction seem to win the day in both the private sphere and the public life of Western civilization.

In the third section as well, personal events are closely connected to the larger social and cultural context of conflict and anxiety. The focalizer is Briony, who works as a nurse during the war, tending to wounded soldiers in an effort to make amends for her own crime. Briony dreams of meeting Robbie and caring for him: "she would dress his wounds" and thus hopefully be forgiven (McEwan 2002, 98). Implicitly, the cruelty of Briony's crime is connected to the cruelty of war, and Briony's early misjudgment seems to form part of the general bleak picture of twentieth-century European history, in which initially poor judgments of Fascism and Nazism had horrible effects. ${ }^{11}$ Some of these effects are seen in the hospital in bodily images of a terrible pain. However, when Briony dares to contact her sister, she learns that the effects of her own crime have been somehow mitigated: Robbie and Cecilia have recovered and are reunited, and they will live together happily ever after (McEwan 2002, 338).

Yet, at the end of the novel the readers learn that Briony, now seventyseven years old and a successful novelist, is the fictional implied author of the whole novel, and that "it is only in this last version that my lovers end well” (McEwan 2002, 370). The readers have been deceived. The promised ending of "happily ever after" is a fictional lie. Briony outlines another version of the story, one in which Robbie dies at Dunkirk and Cecilia is killed by a bomb in London three months later (McEwan 2002, 370). Martin Jacobi refuses to accept this elimination of the happy ending as the definitive interpretation of the novel and claims that the narrative leaves open the possibility that Robbie and Cecilia "did survive and flourish" (Jacobi 2011, 68). Yet, the crucial revelation of Briony's fictional authorship and the "convenient distortion[s]" she admits to having included in her narrative (McEwan 2002, 356)

11 See Brian Finney, who notes "a connection between the microcosm of the lives that Briony has disrupted and the macrocosm of a world at war" (Finney 2004, 73). See also Dominic Head (2007, 171). 
make the readers suspicious of such a happy ending. As Jonathan Kertzer writes, poetic justice rests on "a willing suspension of disbelief," in that the readers accept the supposition of a justice "unavailable in ordinary life" (Kertzer 2010, 11). Atonement destroys this suspension of disbelief and makes the just outcome - Robbie and Cecilia's reunion - part of Briony's immoral deceitful storytelling: she seems to force poetic justice so as to create hope and satisfaction in a cruel and hopeless world.

The unexpected twist at the end of the third section pulls the rug from under the realistic reading of the novel and destabilizes the coherent picture constructed by the readers. It is true that metafictional elements permeate the novel as of its first pages (Finney, 2004). Nonetheless, the concluding section turns the novel into "a self-conscious, self-reflexive novel employing a character narrator who is herself a novelist” (Phelan 2007, 109), which produces an unsettling shock for most readers. I believe that this shock plays an important role in the novel's engagement with the ethical, as it upends the knowing ego of the readers, dismantles the narrative construction, and calls attention to essential dimensions of humanity that exceed representation and narration while still demanding responsibility and responsiveness.

The questioning of the knowing ego develops early in the novel, in the complicity that McEwan creates between closed and totalizing structures of representation - such as those that the young Briony adheres to - and egoistic, imperialistic subjectivity that is blind to the suffering of others. As the first section reveals, Briony's false accusation against Robbie is driven by her passion for such closed narratives with their aesthetic, neat form that provides clear meaning and coherence to the world. An emerging author, the young Briony writes romantic short stories and dramas that reveal "her wish for a harmonious, organized world" (McEwan 2002, 5). As the narrator explains, her desire is "to have the world just so" (McEwan 2002, 4), and therefore she invents schematic and hermetically sealed stories that satisfy "her controlling demon" (McEwan 2002, 5). Thus, when Briony bumps into Lola on that dark night and sees "a figure [. . . ] backing away from her [Lola] and beginning to fade into the darker background of the trees" (McEwan 2002, 164), she immediately creates a sealed story, in which Robbie, whom she has already crowned as an "incarnation of evil" (McEwan 2002, 115), is the perpetrator: "Everything connected. It was her own discovery. It was her story, the one that was writing itself around her. 'It was Robbie, wasn't it?’” (McEwan 2002, 166) In Briony's well-connected story, Robbie, the son of the Tallises' servant, who earlier that day had sent Cecilia an obscene love letter that Briony interprets as "brutal" (McEwan 2002, 113), becomes Lola's rapist. Stripped of his unique individuality, Robbie turns into the missing link in Briony's imaginative chain: he is the obvious villain. 
Briony has no doubt, because "the affair was too consistent, too symmetrical to be anything other than what she said it was” (McEwan 2002, 168). Briony's story also overlooks Lola's perspective, since Briony "cut[s] her [Lola] off" (McEwan 2002, 166), filling in the gaps before Lola dares to speak and explain what actually happened. Although she was only a witness, and a partial witness, Briony turns herself into a reporter who gives a full account of the event. Earlier we are told that in Briony's childish stories “[a] love of order [...] shaped the principles of justice” (McEwan 2002, 7). Yet, when Briony authors reality according to these principles, her well-organized and connected story leads to a terrible miscarriage of justice. As Brian Finney writes, "forcing life to conform to the aesthetic orderliness of art can have actual tragic consequences" (Finney 2004, 80).

When analyzed through the prism of Levinas's philosophy, these tragic consequences seem to point to crucial connections between some uses (or abuses) of language - as in the case of Briony's reasonably structured and closed narratives - and the relation to the other person as a mere other-than-self. McEwan highlights these connections early in the novel, when the young Briony reflects on the mysterious existence of other minds: "was everyone else really as alive as she was? For example, did her sister really matter to herself, was she as valuable to herself as Briony was?" (McEwan 2002, 36). Critics of the novel often argue that Briony's tragic construction of the story of Lola's rape derives from her childish inability to imagine just that: the fact that other people are "as alive as she was." As Finney writes, her problem is "a failure of imaginative projection (into the other)” (Finney 2004, 80). David K. O'Hara also interprets Briony's fault in terms of her inability to step into the shoes of the other, reading it in light of McEwan's own declaration that “imagining what it is like to be someone other than yourself is at the core of our humanity" (O’Hara 2011, 84).

In this view, the ethical vision of the novel is found exactly here - in Briony's gradual process of learning to imagine the inner perspective of others, which she eventually succeeds in completing: "the novel that we read and that took her [Briony's] adult lifetime to write is her attempt to project herself into the feelings of the two characters whose lives her failure of imagination destroyed" (Finney 2004, 80). O'Hara develops this idea by reading Atonement through the writings of Levinas, Merleau-Ponty, and Zigmunt Bauman. As he writes: "it is Briony's actual writing of the novel that may be her vital act of atonement," since by her fictional writing, the mature Briony is able to convey "what it is like to be other than yourself” (O’Hara 2011, 84; italics in original). Thus, O’Hara suggests seeing Briony as a culmination of Levinas's "being-for," in her "[attempt] to imagine the reality of an Other's experience” (O’Hara 2011, 93). 
Unlike these interpretations of Atonement's ethical stance, my contention is that the novel actually rejects both the ethics of empathy and the idea that Briony's fault lies in her inability to project herself into the feelings of others and simulate their inner perspective. I also reject the argument that Briony's later ability to do so constitutes her moral growth. On the contrary, McEwan turns the readers' attention to the ethical problematics of such an imaginative projection: the elderly Briony sees her novelistic self as having an "absolute power” (McEwan 2002, 371) in a way that corresponds to Levinas's description of "imperialist subjectivity" (Levinas 1991 [1974], 146) rather than his ethical "being-for." The above interpretations assume that imaginative projection into others not only facilitates an understanding of other minds but also promotes ethical relationships and behavior. ${ }^{12}$ However, McEwan questions this idea when he endows Briony with the ability to imagine the independent existence of others before she commits her terrible crime against Robbie and Cecilia, and not after it. This is a crucial point: imaginative projection is an aesthetic development in Briony's initiation story, but it should not be confused with an ethical relation to the other.

Briony's aesthetic change occurs when she witnesses the scene by the fountain and considers how she might turn it into a story. At first she is startled: Cecilia and Robbie meet near the fountain, quarrel over a vase (which then shatters), after which Cecilia removes her clothes and jumps into the water (McEwan 2002, 38-39). This unexpected and incomprehensible unfolding seems "illogical" to Briony, but she then has a sudden realization that helps her gain control over the surprising episode: she can describe it in a narrative by "[entering] these different minds" and representing the scene "from three points of view” (McEwan 2002, 40). McEwan is careful to describe Briony's change in aesthetic terms, leaving the readers to reflect upon the ethical implications: "[she] had written her way through a whole history of literature, beginning with stories derived from the European tradition of folk tales, through drama with simple moral intent, to arrive at an impartial psychological realism which she had discovered for herself, one special morning during a heat wave in 1935” (McEwan 2002, 41).

Briony's understanding of the aesthetic value of "[entering] these different minds" (McEwan 2002, 40) is an important phase in her development as a writer. It is also a process that corresponds to the aesthetic development of Western literature and the emergence of ethical realism: ${ }^{13}$ a tradition that offers

12 On this twofold dimension of empathy see Amy Coplan and Peter Goldie (2011, ix-xvii). 13 On the literary teleology here, see Serpell $(2014,96)$. 
readers a sense of ethical elevation by letting them share the inner perspective of different human beings. However, McEwan implicitly questions the ethical connotations of empathetic realism. Does Briony's new aesthetics make her a better person? Does it make her recognize her own limits regarding other human beings? The unfolding of the plot points to a negative answer. A moment later Briony betrays Robbie, reading his love letter to Cecilia and turning him into "a maniac," despite having known him all her life as a good, kind person. Later that day she will reduce Robbie to a violent criminal in her story of rape, thereby ruining both his and Cecilia's lives. Aesthetic development, McEwan seems to argue, should not be equated with ethical growth.

Instead of viewing the ethical core of the novel as an affirmation of empathetic imagination, I suggest reading it in terms of Levinas's notion of "bearing witness" to the enigma of the other that "strips the ego of its pride and the dominating imperialism characteristic of it" while producing infinite responsibility (Levinas 1991a [1974], 110). Hence, Briony's fault does not lie in her (in)ability to enter the inner world of others, but in her way of turning the encounter with the mystery of the other into an intellectual inquiry that produces a plot with a clear explanation. Indeed, when Briony witnesses the scene at the pond she finds herself confused, and faces what Levinas describes as the "traumatism of astonishment” (Levinas 2002 [1969], 73), i.e., the experience of shock that arises from the encounter with "something absolutely foreign" (Levinas 2002 [1969], 73). Briony is agitated by seeing a scene that she does not understand - a mysterious happening between her sister and Robbie. She cannot interpret it, but "it was extraordinary that she was unable to resist it" (McEwan 2002, 38). Yet, Briony is also unable to resist the temptation to solve the mystery and defy the shock of the incomprehensible by turning it into a story: "Blackmail? Threats?" she wonders (McEwan 2002, 38). As of her first questions Briony begins to form a plot, and she continues by calming herself: "she could see the simple sentences [. . .] she could write the scene three times over" (McEwan 2002, 40). When confronted with what Levinas terms "the horror of the radical unknown" (Levinas 2002 [1969], 41), Briony resorts to constructing stories, thus turning the other into an intelligible character rather than recognizing her own limitations and obligations in this incomprehensibility.

By the end of the novel it is clear that Briony has gone a long way from her childish folktales of villains and princesses to writing the absorbing novel we have just read with its varying focalizations and realistic impressions. Nevertheless, the surprising revelation of her authorship further undermines the ties between empathetic imagination of other selves and ethical concern for the other. It is true that "her narrative so sympathetically enters into the consciousness of the other characters" (Phelan 2007, 122). However, her signature 
at the end of the third section highlights the fabrication behind any sympathetic simulation of another person's perspective. In fact, Briony's construction of the stories of Robbie and Cecilia - which is acutely beautiful and convincing - relies upon her own perspective, her understanding of the events and her interpretation of their experience. Indeed, it is "her [Briony's] absolute power" that constructs every aspect of the story, every character and perspective, amounting to the position of "God" (McEwan 2002, 371) - a dominating force that determines everything in the represented world. ${ }^{14}$

McEwan's suggestion of the God-like position of the author hints at his own position as the author of Atonement and at the broader issue of the ethics of fiction writing. This is why Dominic Head notes that "the actions of the novelist might always be morally dubious" (Head 2007, 166; italics in original). However, I believe that Atonement points to another possibility rather than concluding with moral skepticism. In the invitation to re-read the novel, which arises from the surprising revelation of Briony's authorship, McEwan points to a different vision of the ethical - behind Briony's authority and beyond the language of representation and empathetic understanding. In this second reading we can see the novel's exploration of both the evil spirits populating European history and those that operate in the individual soul - as part of its insistence on the obligation to care for the singularity of the other person. In the double reading of Atonement, the novel appears not only to acknowledge the human desire to provide a definitive explanation for the world, but also to insist on the impossibility of doing so and the obligation that arises from this impossibility.

In the second section of Atonement, Robbie considers the impossibility of giving witness to his war experiences: "[. . .] - the place was rubble and it was impossible to tell. Who would care? Who could ever describe this confusion [. . .] No one would ever know what it was like to be here. Without the details there could be no larger picture" (McEwan 2002, 227). The response to Robbie's skepticism emerges in Briony's attempts to achieve representation in her many drafts of the novel. Briony tries hard to believe that she can tell; that she can present the larger picture, enter Robbie's perspective, and convey his experience of war. However, the delayed revelation of her authorship of the novel indicates that this representation is in fact a lie, a deceitful depiction. The structure of Atonement is witness to the fact that literature cannot paint the larger picture and do justice to the truth of history or the individual experience

14 Moreover, as Phelan argues, McEwan "actually call[s] attention to the fact that [Briony's] long delay in finishing her novel has also been a way to avoid taking the one concrete step toward atonement available to her: the public admission of her crime [. . .] and the effort to clear Robbie's name” (Phelan 2007, 126). 
of "what it was like to be [there]." Moreover, the novel forces the readers to face their own complicity with Briony's deception: just like Briony we were eager to believe that we can "know what it was like to be [there]." Yet just like Briony, we cannot. We can only fake this knowledge and pretend to share the experience of war. As Serpell argues, "we [the readers] are accused - framed - by the text” (Serpell 2014, 88).

Reading Atonement through Levinas is thus a process of self-critique that demands awareness not only of the readers' desire for a happy ending, just like Briony's, but also their desire to enjoy the consolation of stories that "bridge the distance between self and other" (Palambu-Liu 2012, 29). These are stories that organize human reality into a meaningful and comprehensible framework, what Levinas describes as a "system - complete, perfect, denying or absorbing the differences that appear to betray or limit it" (Levinas 1996, 5). Yet Atonement's unexpected conclusion dismantles this complete and perfect system, thus allowing the readers to see their attachment to it and recognize their complicity with Briony's efforts to turn the unknown and the unimaginable into comprehensible components of this perfect system.

In addition, however, apart from the question of knowledge, the preceding quote also raises the question of caring: "Who would care?" In the first reading of the novel, caring seems completely dependent on knowing: if it is impossible to tell and to know, then no one will care. By contrast, in the second reading, this relationship between knowing and caring are seen as part of Briony's attitude and her authorial domination: she, as an author, is resolved to determine what is known and what is cared for. However, in the story of Robbie's trial another view about caring is hinted at: namely, the obligation to care that emanates precisely from the impossibility to tell and to know, the responsibility to that human suffering that cannot be described and shared.

This obligation emerges early in Robbie's section when he comes across "the unexpected detail" of a human leg in a tree (McEwan 2002, 191). The encounter replicates Briony's experience of the shock of the unexpected when she witnesses the scene near the pond, but here the development is different:

The leg was twenty feet up, wedged in the first forking of the trunk, bare, severed cleanly above the knee. From where they stood there was no sign of blood or torn flesh. It was a perfect leg, pale, smooth, small enough to be a child's. The way it was angled in the fork, it seemed to be on display, for their benefit or enlightenment: this is a leg.

(McEwan 2002, 192)

Unlike Briony's puzzlement when witnessing the incomprehensible spectacle, here the image is very clear and simple: "this is a leg." Nevertheless, it is a 
horrifying image for both Robbie and the readers. Rereading the novel, the readers already know that Briony is describing everything. Thus, it is significant that unlike her early rush to invent a story after seeing the shocking episode near the pond, here the story pauses. Witnessing does not turn into storytelling. There is no narrative, no plot, no explanation. There is only a sign: "this is a leg." Although the leg is "on display," there is a great deal that cannot be seen and cannot be said: the novel does not tell the story of how the leg came to be there. The story of the human being, perhaps a boy who lost his leg, is also missing.

The leg is a dreadful image. J. Hillis Miller discusses its horrifying effect in terms of the "traumatic doubling" that attentive readers experience when associating this leg with an earlier image of Briony's mother's leg in the first section of the novel (Miller 2013, 97). But even more so, it is the untold violence and unrepresented suffering that cause the shock here. Indeed, the leg determines the limits of representation of Briony's narration and of McEwan's writing. The text seems to declare the impossibility of giving an account of the deep suffering experienced by the human being who lost a leg. The "perfect leg," with "no sign of blood or torn flesh," signifies horrific pain, which, contrary to Briony's aim of telling all, cannot be told. Thus, the leg is a synecdoche for the face, which itself is "abstract" and "invisible" even as it signifies the precariousness of the other. Levinas describes several parts of the body in these terms when he refers to a scene in Vasily Grossman's novel Life and Fate in which the human back, neck, and shoulders become painfully expressive and ethically demanding. ${ }^{15}$

In Atonement, Robbie is deeply disturbed by the leg: "All he wanted [. . .] was to forget about the leg" (McEwan 2002, 193), but it does not stop haunting him: "He was trying to push it away, but it would not let him go" (McEwan 2002, 194). The leg pervades Robbie's thoughts and hallucinations and at times it seems as though it is speaking to him, pointing to what is missing: "a vanished boy. Vanished" (McEwan 2002, 202). All that can be told is a lacuna, a void.

Yet near the end of this section, something else develops, when the wounded Robbie, probably in his dying moments, acknowledges the command emanating from the leg and its missing story: "He must go back and get the boy from the

15 See Levinas's reference, in "Peace and Proximity," to an episode in Grossman's novel when the backs and raised shoulders of people in a line at Lubyanka prison embody the vulnerable enigma of the face (Levinas 1996a, 167). In later interviews Levinas refers again to this episode and points to the nape of the neck as an expression of the face (Levinas 2001, 192, 208). 
tree" (McEwan 2002, 262). Here, the unknown and the ineffable provoke the obligation to care. Robbie's feverish delusions continue with a vision of his reverse journey:

So he would go back the way he had come, walk back through the reverses of all they had achieved, across the drained and dreary marshes, past the fierce sergeant on the bridge, through the bombed- up village, [. . .] and next day, in yellow morning light, on the swing of a compass needle, hurry through that glorious country of little valleys and streams and swarming bees, and take the rising footpath to the sad cottage by the railway. And the tree. Gather up from the mud the pieces of burned, striped cloth, the shreds of his pyjamas, then bring him down, the poor pale boy.

(McEwan 2002, 262)

Robbie dreams of undoing the plot of war, reversing the narrative step by step so that he can return to that vanished boy. It is the undoing of all that has been done that can change everything, reverse the extreme violence that severed this leg from a living human being, annul the crimes of the terrible war, and overturn Briony's accusation of Robbie. This is Robbie's fantasy, or perhaps Briony's, or McEwan's dream of rewinding the traumatic record of the twentieth century and re-writing the history of Europe. The readers know that this cannot be done. Literature cannot change the past, cannot atone for crimes, and cannot offer a full accounting of human lives and the distinct experience of others.

However, in re-reading the novel another possibility takes shape in this dream of undoing. Robbie's dream is driven by the bond of responsibility, and it is this bond that Atonement tries to convey. The dream of undoing the plot is also the dream of undoing the Said of the narrative, so that the Saying can be approximated: the infinite responsibility for the suffering of another human being whose pain can never be fully narrated or shared. Judith Butler comments that "the human is indirectly affirmed in that very disjunction that makes representation impossible [...]. There is something unrepresentable that we nevertheless seek to represent, and that paradox must be retained in the representation we give" (Butler 2004, 144). McEwan's Atonement addresses exactly this paradox, giving Briony the authority to represent but then admitting that representation is necessarily limited, misleading, and flawed. Yet even if representation and narration necessarily miss or distort the otherness of the other, Atonement nonetheless tries to articulate the essential indebtedness of its narrative to "what is precarious in another life" (Butler 2004, 134).

Robbie's fantasy of rewinding the plot, like Briony's wish of amending her crime, can be read as the novel's fantasy of undoing the said of its representation to signify the plot of proximity, the ethical "for-the-other." This primal responsibility of the self to the other is the basic relation that is ignored and rejected in 
both Briony's plot of accusation and the historical plot of the terrible war. As the novel sends the readers to re-read its plot, after the surprising ending, it also invites the readers to realize that the crime of overlooking the singularity of the other is at the root of human atrocities.

Reading Atonement through the ethical perspective of Levinas's thought thus calls for an effort to reach beyond Briony's captivating narration, beyond the understanding of others promised by realism, and beyond McEwan's skeptical suggestion that storytelling is always deceptive and misleading and thus, as Head claims, "morally dubious" (Head 2007, 166). Instead, the novel draws attention to the potential of fiction to bear witness to the infinite indebtedness to the singularity of the other. It demands being attentive to narrative lapses, absences, omissions, duplications, and inconsistencies - discursive features that disrupt the narrative construction and the fluidity of reading - where the relation to "the other than self" can be approached as the unsaid of what is said. Atonement explores this potential of fiction. Beyond the well-connected plot, the novel calls upon its readers to re-read this basic relation to the other person as part of the act of narration itself that is committed to and embedded in the vulnerability of human life.

\section{Works Cited}

Amiel Houser, Tammy, and Adia Mendelson-Maoz. "Against Empathy: Levinas and Ethical Criticism in the Twenty-First Century." Journal of Literary Theory 8.1 (2014): 199-218.

Attridge, Derek. "Ethical Modernism: Servants as Others in J. M. Coetzee’s Early Work." Poetics Today 25.4 (2004): 653-671.

Bernasconi, Robert, and Critchley Simon (Eds.) Re-reading Levinas. Bloomington: Indiana University Press, 1991.

Black, Shameem. Fiction across Borders: Imagining the Lives of Others in Late-TwentiethCentury Novels. New York: Columbia University Press, 2010.

Butler, Judith. Precarious Life: The Powers of Mourning and Violence. New York: Verso, 2004.

Carroll, Noël. "The wheel of Virtue: Art, Literature and Moral knowledge." The Journal of Aesthetics and Art Criticism 60.1 (2002): 3-26.

Critchley, Simon, The Ethics of Deconstruction: Derrida and Levinas. Edinburgh: Edinburgh University Press, 1999.

Coplan, Amy and Peter Goldie. "Introduction." Empathy: Philosophical and Psychological Perspectives. Eds. Amy Coplan and Peter Goldie. Oxford: Oxford University Press. 2011, IX-XLVII.

Currie, Gregory. “The Moral Psychology of Fiction.” Australian Journal of Philosophy. 73.2 (1995): 250-259.

Derrida, Jacques. "Violence and Metaphysics: An Essay on the Thought of Emmanuel Levinas." Trans. Alan Bass. Writing and Difference. Chicago: The University of Chicago Press, 1978, 79-153. 
Eaglestone, Robert. Ethical Criticism: Reading after Levinas. Edinburgh: Edinburgh University Press, 1997.

Finney, Brian. "Briony's Stand against Oblivion: The Making of Fiction in Ian McEwan's Atonement." Journal of Modern Literature 27.3 (2004): 68-82.

Fraser, Ian. “Class Experience in McEwan's Atonement." Critique 54.4 (2013): 465-477.

Genesis. The New Oxford Annotated Bible. Ed. Michael D. Coogan. New York: Oxford University Press, 2007.

Greiner, Rae. Sympathetic Realism in Nineteenth-Century British Fiction. Baltimore: Johns Hopkins University Press, 2012.

Hale, Dorothy J. "Fiction as Restriction: Self-Binding in New Ethical Theories of the Novel." Narrative 15.2 (2007): 187-206.

Hammond, Meghan Marie, and Sue J. Kim (Eds.). Rethinking Empathy through Literature. New York: Routledge, 2014.

Harrison, Mary-Catherine. "The Paradox of Fiction and the Ethics of Empathy: Reconceiving Dickens's Realism.” Narrative 16.3 (2008): 256-278.

Head, Dominic. Ian McEwan. Manchester and New York: Manchester University Press, 2007.

Hollander, Rachel. "Daniel Deronda and the Ethics of Alterity." Levinas and Nineteenth-Century Literature: Ethics and Otherness from Romanticism through Realism. Eds. Donald R. Wehrs and David P. Haney. Newark: University of Delaware Press, 2009. 264-287.

Jacobi, Martin. "Who Killed Robbie and Cecilia? Reading and Misreading Ian McEwan's Atonement." Critique 52.1 (2011): 55-73.

Kertzer, Jonathan. Poetic Justice and Legal Fictions. Cambridge: Cambridge University Press, 2010.

Kronick, Joseph K. "Levinas and the Plot against Literature." Philosophy and Literature 40.1 (2016): 265-272.

Levinas, Emmanuel. Otherwise than Being or beyond Essence. Trans. Alphonso Lingis. Dordrecht: Kluwer Academic, 1991a [1974].

Levinas, Emmanuel. “Wholly Otherwise” [1973]. Trans. Simon Critchley. Re-reading Levinas. Eds. Robert Bernasconi and Simon Critchley. Bloomington: Indiana University Press, 1991b. 3-8.

Levinas, Emmanuel. "Peace and proximity." Basic Philosophical Writings. Eds. Adriaan T. Peperzak, Simon Critchley, and Robert Bernasconi. Bloomington: Indiana University Press, 1996a. 161-170.

Levinas, Emmanuel. Proper Names. Trans. Michael B. Smith. Stanford: Stanford University Press, 1996b [1975].

Levinas, Emmanuel. Is it Righteous to be? Interviews with Emmanuel Levinas. Ed. Jill Robbins. Stanford: Stanford University Press, 2001.

Levinas, Emmanuel. Totality and Infinity: An Essay on Exteriority. Trans. Alphonso Lingis. Pittsburgh: Duquesne University Press, 2002 [1969].

Maitzen, Rohan. 'The Soul of Art': Understanding Victorian Ethical Criticism. ESC: English Studies in Canada, 31.2-3 (2005): 151-185.

Marshal, Gregory. "Redefining Ethical Criticism: The Old vs. the New." Journal of Literary Theory 4.2 (2010): 273-302.

McEwan, Ian. Atonement. London: Vintage, 2002 [2001]. 
Miller, J. Hillis. "Some Versions of Romance Trauma as Generated by Realist Detail in Ian McEwan's Atonement." Trauma and Romance in Contemporary British Literature. Eds. Susana Onega and Jean-Michel Ganteau. New York: Routledge, 2013. 90-106.

New, Melvyn, Robert Bernasconi, and Richard A. Cohen (Eds.). In Proximity: Emmanuel Levinas and the Eighteenth Century. Lubbock: Texas Tech University Press, 2001.

Nussbaum, Martha C. "Exactly and Responsibly: A Defense of Ethical Criticism.” Mapping the Ethical Turn: A Reader in Ethics, Culture, and Literary Theory. Eds. Todd F. Davis and Kenneth Womack. Charlottesville: University of Virginia Press, 2001. 59-77.

O’Hara, David K. “Briony's Being-For: Metafictional Narrative Ethics in Ian McEwan's Atonement." Critique 52.1 (2011): 72-100.

Palambu-Liu, David. The Deliverance of Others: Reading Literature in a Global Age. Durham: Duke University Press, 2012.

Phelan, James. "Delayed Disclosure and the Problem of Other Minds: Ian McEwan's Atonement." Experiencing Fiction: Judgments, Progressions, and the Rhetorical Theory of Narrative. Columbus: The Ohio State University Press, 2007, 109-132.

Robbins, Jill. Altered Reading: Levinas and Literature. Chicago: Chicago University Press, 1999.

Serpell, C. Namwali. Seven Modes of Uncertainty. Cambridge: Harvard University Press, 2014.

Wehrs, Donald R., and David P. Haney (Eds.). Levinas and Nineteenth-Century Literature: Ethics and Otherness from Romanticism to Realism. Newark: University of Delaware Press, 2009. 
